\title{
MONITORING, RESTORATION AND MAINTENANCE OF AGED TREES IN SUMMER AND MIKHAILOVSKY GARDENS OF ST. PETERSBURG
}

\author{
O.A. Cherdantseva ${ }^{1}$, E.A. Lukmazova ${ }^{1}$, \\ A.G. Dmitrieva ${ }^{2}$, T.A. Dubrovina ${ }^{2}$ \\ ${ }^{1}$ Russian Museum \\ Inzhenernaya str., 4, St. Petersburg, Russia, 191186 \\ ${ }^{2}$ RUDN University \\ Miklukho-Maklay str., 8/9, Moscow, Russia, 117198
}

\begin{abstract}
The image of the Summer Garden is inseparable from the image of St. Petersburg. It was survived together with the city of the period of formation, rapid flourishing, change of rulers, change, economic systems, natural and military disasters. In June 2009, Russian Museum proceeded to largest restoration on the reconstruction of the memorial ensemble of the Summer garden. The article presents the results of inspection condition of old-growth trees in Summer and Mikhailovsky Gardens and analyze inventory data from 1962 to 2014, the dynamics of change in the number of trees.
\end{abstract}

Key words: Summer Garden, Mikhailovsky Garden, plantations of trees, inventory of tree plantations, old-growth trees

\section{INTRODUCTION}

Urban green zones make a substantial contribution to the environmental conditions and the quality of life in the modern cities. For example, trees and shrubs in the leafy state reduce dust in the air an average of $40 \%$ [7]. Old rural parks resemble high-conservationvalue forests more than the best preserved contemporary forest remnants. Old parks do provide a refugium for temperate deciduous forest species [1].

Under specific circumstances the old trees in the park may provide valuable information for restoration decisions. The most important challenge in restoration is to identify trees and provide conditions to achieve an original design concept. Due the similar trends in development of manors and manor parks in the Baltic countries, the topic is equally interesting for all Baltic States.

Reconstruction and design of the original landscape requires the inventory data, including total amount, age, dominated species and the structure of plantations. Furthermore, the difference between the current structure and the original plan shall be considered by the landscape architectures and planners. One of the ways to deal with this issue is to identify the really old trees from the new or subsequent growth, and focus attention on those [2].

Since the old trees illustrate a long period of environmental conditions' dynamics, investigators are increasingly turning to dendrochronology to create context for current environmental change. While a suite of characteristics to identify old trees has been developed, most of these characteristics are for conifers or trees growing in low-density forests. The common indicators of old ( $>250$ year old) EDF angiosperms are presented to aid in the recovery and preservation of these living sources of information [3]. This 
study aimed to analyze the inventory and dendrochronological information for two historical parks in Saint Peterburg in order to develop the best management practice to restore and maintain the plantations.

\section{MATERIAL AND METHODS}

The research area included to historic gardens, located in the center part of SaintPetersburg $\left(59^{\circ} 57^{\prime} \mathrm{N} ; 30^{\circ} 18^{\prime} \mathrm{E}\right)$. Both areas were passed the management of the Russian Museum to create a single palace-garden complex in the center of St. Petersburg. The Mikhailovsky Garden with Mikhailovsky Castle Garden and Engineers Square was included in the complex in 1998, whereas the Summer Garden with a summer palace of Peter I and the house of Peter I on Petrovsky Embankment was embraced in 2004.

Restoring the historical gardens was claimed as the principal goal for the established palace-garden complex. An new branch of the Russian Museum, focused on the green areas of the Summer and Mikhailovsky Gardens was established in 2012. An inventory of the green areas was performed and the research and restoration activities were organized to maintain and develop the garden ensemble. Although the inventories in the Mikhailovsky Garden were conducted previously (in 2011 before the restoration and in 2008 after the restoration), the inventory results were not complete. A new inventory of the gardens and green areas was carried out in 2012-2014 to fill existing data gaps. Since the age of the trees was not specified in the previous inventories, trees of each type (breed) with different diameters were sampled and the age category was identified. Selected aged (older than 150 years) trees were analyzed with the two-dimensional impulse tomography Arbotom (Rinntech, Germany) (in total 300 trees). The selected ancient trees in the Mikhailovsky Garden (for example, an oak dated back to the Peter I period and overmature lime-trees) were additionally examined by specialists of NCSA's and the core samples were taken. The obtained results on the age of the trees were verified using the historical documents (for example, the greening plan of Rastrelli). The inventory results were used to develop the best management strategies to maintain the plantations. A comprehensive monitoring of plantations' state was carried out to evaluate the efficiency of the implemented managements.

\section{RESULTS AND DISCUSSIONS}

In inventory results reveals the predominance of old trees in both Summer and Mikhailovsky Gardens (Table 1).

Table 1

Number of trees by age group, years

\begin{tabular}{|l|c|c|c|c|c|c|c|c|}
\hline \multirow{2}{*}{ The name of the garden } & \multicolumn{2}{|c|}{ up to 40} & \multicolumn{2}{c|}{$40-100$} & \multicolumn{2}{c|}{ Over 100} & \multicolumn{2}{c|}{ Total } \\
\cline { 2 - 9 } & Pcs. & $\%$ & Pcs. & $\%$ & Pcs. & $\%$ & Pcs. & $\%$ \\
\hline The Summer Garden & 256 & 13,5 & 582 & 30,6 & 1063 & 55,9 & 1901 & 100 \\
\hline The Mikhailovsky Garden & 200 & 17,0 & 392 & 33,0 & 595 & 50,0 & 1187 & 100 \\
\hline
\end{tabular}

The obtained results were compared with the historical data, obtained for the green plantations of the Summer Garden in 1930 - 1940-s. The oaks of the age up to 500 years were the oldest trees in the garden in 1940-s, whereas the oldest lime-trees 
were 250 years old, and larch trees aged 200-300 years [8]. The comparative analysis of the inventory data collected at the Summer Garden for the period 1962-2012 years reveals that the oldest trees ( 200 years or older) are represented by lime trees and single oak trees. Similar results were obtained for the Mikhailovsky Gaden, where lime trees and single oaks were the oldest trees. The aged of the trees was not always positively correlated with the diameter, indicating that a larger diameter not always corresponds to an older age.

The aged trees are vulnerable to climatic conditions (e.g. windfalls and droughts) and anthropogenic pressures and therefore require for the special maintenance treatments. Prior restoration of the Summer garden comprehensive measures to adapt the trees to stressful situation was carried out. According to our information, it was for the first time in Russia. Several treatments were implemented. Sanitary, forming, decimation and compensating pruning of trees was carried out. The 44 problematic trees (curved and branched specimens) have been lowered to one-third or half of the initial height to preserve the trees and improve the light conditions. Root and leaf nutrition and treatments with biostimulators were implemented several times. The revealed 518 hollows (including 230 high from the surface) and frost cracks were treated. More than 100 young trees were planted and 21 trees were relocated during the restoration of the Summer Garden [5]. The implemented measures substantially increased the sustainability of the plantations. As seen from Figure 1 plants' health condition (in score) after reconstruction in the Summer Garden in 2012 was better when compared with before reconstruction in 2006-2007 years. During the four-year period after the restoration windfalls in the Summer Garden did not occur [6].

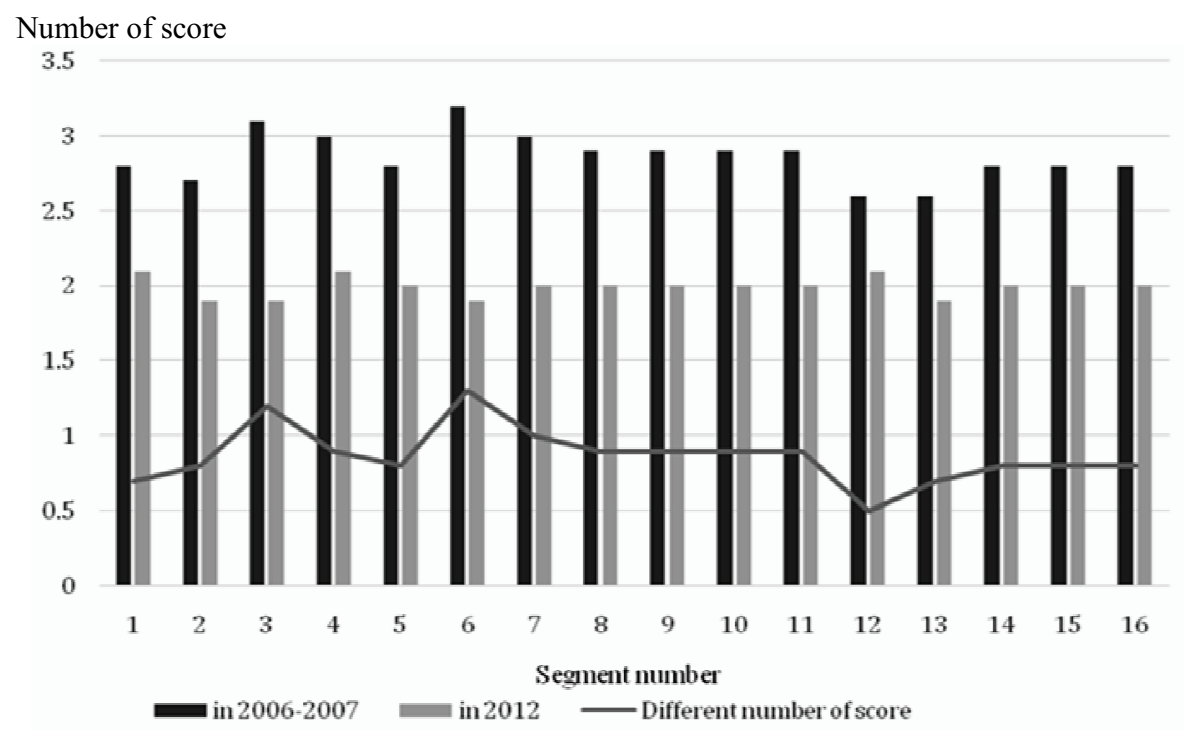

Figure 1 Comparison of plants' health condition before and after reconstruction in the Summer Garden

The treatment of the aged trees was carried out in the Mikhailovsky Garden during the restoration in $2000-2003$. The following measures were taken: pruning, treatment of hollows and frost cracks, installation of protective and supportive structures. 
The drainage pipes were installed in the Mikhailovsky Garden, however their effectiveness was not proved. For example, the examination of the tubes carried out during the plantations' monitoring showed that the tubes did not functions partly because they were clogged with rotting wood and rot, partly because the lowering of the hollow's boundaries. Since the effectiveness of the drain tubes was not confirmed for the Mikhailovsky Garden, they were not implemented for the Summer garden afterwards.

Currently, the following managements are implemented to all aged trees in the garden: sanitary pruning, moulding pruning and thinning of the crown (once a year), treatment with pesticides (twice a year). The aged trees in printed coverage in the Summer garden also received foliar fertilization until 2016 was. The following measures are implemented to treat the trunks: stem growth is removed, hollows are treated with further examining and treating sprout and truck damages.

Comparative monitoring of the aged trees' state was carried out in both gardens in 2016. In result 274 hollows were fixed in the Summer Garden, whereas 76 hollows were found in the Mikhailovsky Garden. The 92 crowns and trunks are fixed with ties in the Summer Garden, which is almost three time more than in the Mikhailovsky. Besides, 3 clamps and 1 holder were mounted on trunks during the restoration period. The positive experience of lowering tree in Summer garden were implemented in the Mikhailovsky Garden to restore the plantations.

To effectiveness of the implemented maintenance measures was evaluated based on monitored of the plantations' conditions. It was found, that the sanitary score of the plantations' conditions didn't changes since 2012 and gave similar 2.0 in average for the Summer garden [5]. The same score was obtained for the Mikhailovsky Garden. A major part of the trees in the gardens of the Russian Museum belongs to the second category (Table 2). The elm trees usually belong to the fourth category, whereas the first category is mainly reported for the young plantations. However, some of the young trees don't correspond to the first category to strong shadowing under crones.

Table 2

Distribution of trees between the state categories (August 2016), Pcs.

\begin{tabular}{|l|c|c|c|c|c|c|c|c|c|c|}
\hline \multicolumn{1}{|c|}{ Garden } & \multicolumn{5}{c|}{ The Summer Garden } & \multicolumn{5}{c|}{ The Mikhailosky Garden } \\
\hline Category condition & 1 & 2 & 3 & 4 & Total & 1 & 2 & 3 & 4 & Total \\
\hline Number of trees & 105 & 1663 & 88 & 0 & 1861 & 101 & 1020 & 62 & 1 & 1184 \\
\hline$\%$ & 5,66 & 89,61 & 4,73 & 0 & 100 & 8,53 & 86,15 & 5,24 & 0,08 & 100 \\
\hline
\end{tabular}

The applications for the two historical trees in the gardens were submitted in summer 2013 to the Russian program "Tree — is a monument of nature". Those trees were the oak of time of Peter the Great and the maple, located near the Palace of Peter I and frequently encountered in the paintings and engravings of the late XIX - early XX centuries of the Summer garden and the. In result both trees were included in the Register of Russian old-growth trees the end of 2013. The trees were officially recognized as "tree-monuments of nature" in winter 2014 by the decision of the Commission.

The analysis of the overmature lime-tees' showed an absence of rot for one of them. Based on the three sampled cores 265 and 267 annual rings were detected at [4]. The age 
of the tree-monument of nature - an old oak tree, located on an Oil meadow of the Mikhailovsky Garden, was estimated to 278 years. This outcome incorporated with the analysis of iconographic materials alowed Cherdantseva to draw conclusions that the oak was planted during the reconstruction of the garden following the project Rasstrelli's plan of 1741, organized for the Empress Elizabeth Petrovna. Therefore there are evidences to call this oak "The tree of Elizabethan time". The core analysis of the other limetrees allowed interpolating its age to 286 years. There are 90 lime-trees of the similar age in the Summer Garden and 70 - in the Mikhailovsky Garden. Up to 27 aged trees (including 20 elm trees) were cut and 4 young tree were planted in the Summer garden since 2012. In total 24 aged trees were cut in the Mikhailovsky Garden, including 10 trees, affected by the 'ulm' disease.

The Mikhailovsky Garden hosted charity event "Tree of life" for the first time in 2014. Celebrities in the cultural, scientific and business spheres planted new trees within this action. The memorial name plates were with personal names or the names of the company were attached to the trunks of the trees. Each participant received a medal and a certificate. In total 28 new trees were planted to replace the dead aged trees during last two years. Planting trees in the historic garden is the best way to preserve the memory of yourself for future generations, because the trees live for centuries. Every planted tree males an invaluable contribution to the restoration of the architectural-spatial composition of the historical gardens. Although, the total extent of the Central Imperial gardens of Peter the Great in St. Petersburg reduced substantially over last 300, their significance and impact on the environment as the 'green lung of the city center' it is difficult to overestimate [6]. Therefore, it is important to keep them in appropriate condition and to preserve old-growth stands of past eras!

(C) O.A. Cherdantseva, E.A. Lukmazova, A.G. Dmitrieva, T.A. Dubrovina, 2016

\section{REFERENCES}

[1] Lõhmus K., Liira J. Old rural parks support higher biodiversity than forest remnants, Basic and Applied Ecology, Germany, Volume 14, Issue 2, March 2013, P. 165-173.

[2] Nutt, N., Nurme, S., Hiob, M., et al. Restoring manor parks: Exploring and specifying original design and character through the study of dendrologous plants in estonianhistorica manor parks, Baltic Forestry, Volume 19, Issue 2, 2013, P. 280-288.

[3] Pederson, N. External characteristics of oldtrees in the eastern deciduous forest, Natural Areas Journal, Volume 30, Issue 4, October 2010, P. 396- 407.

[4] Lovelius N.V., Lukmazova E.A., Palchikov S.B. et al. Linden overmature generation in the Summer garden of St. Petersburg // Geography: the development of science and education. A collective monograph on the International scientific-practical conference LXVIII Gertsenovskie reading 22-25 April 2015, devoted to the 70th anniversary of UNESCO. SPb. Publishing house of the Herzen State Pedagogical University of Russia. P. 91-95.

[5] Lukmazova E.A., Cerdanceva O.A. Changing the condition of green plantings in the Summer Garden in St. Petersburg after reconstruction // RUDN Journal of Agronomy and Animal Industries, № 5. M., 2012. P. 33-42. 
[6] Mosina L.V., Dovletyarova E.A. Forest experimental cottage RSAU — MAA named after K.A. Timiryazev as an object of ecological monitoring of forest and forest park landscapes Moscow metropolis. PFUR, 2014, P. 1-221.

[7] Petrovskaya P.A., Stolyarova A.G. The basic principles of urban environment landscaping // RUDN Journal of Agronomy and Animal Industries,, № 5, M., 2013. P. 93-100.

[8] Dubyago T.B. The Summer garden. M.-L., 1951.

DOI: $10.22363 / 2312-797 X-2016-4-45-50$

\title{
СОХРАНЕНИЕ СТАРОВОЗРАСТНЫХ ДЕРЕВЬЕВ И МОНИТОРИНГ ИХ СОСТОЯНИЯ В ЛЕТНЕМ И МИХАЙЛОВСКОМ САДАХ САНКТ-ПЕТЕРБУРГА
}

\author{
О.А. Черданцева ${ }^{1}$, Е.А. Лукмазова ${ }^{1}$, \\ А.Г. Дмитриева ${ }^{2}$, Т.А. Дубровина ${ }^{2}$ \\ ${ }^{1}$ Русский музей \\ Инженерная ул., 4, Санкт-Петербург, Россия, 191186 \\ ${ }^{2}$ Российский университет дружбы народов \\ ул. Миклухо-Маклая, 8/2, Москва, Россия, 117198
}

\begin{abstract}
Образ Летнего сада неотделим от образа Санкт-Петербурга. Он пережил вместе с городом период становления, бурного расцвета, смену правителей, экономических формаций, стихийных и военных бедствий. В июне 2009 г. Русский музей приступил к крупнейшей реставрации по воссозданию ансамбля-памятника Летний сад. В статье приводятся результаты обследования состояния старовозрастных деревьев Летнего и Михайловского садов и анализ инвентаризационных данных с 1962 по 2014 г. динамики изменения количества деревьев.
\end{abstract}

Ключевые слова: Летний сад, Михайловский сад, зеленые насаждения, инвентаризация древесных насаждений, старовозрастные деревья 